\title{
Miranda
}

Revue pluridisciplinaire du monde anglophone /

Multidisciplinary peer-reviewed journal on the English-

speaking world

13 | 2016

Thomas Spence and his Legacy: Bicentennial

Perspectives

\section{The Debate on Property during the First English Revolution 1647-1659 : A Historical Perspective}

\section{Myriam-Isabelle Ducrocq}

\section{(2) OpenEdition}

\section{Journals}

\section{Electronic version}

URL: http://journals.openedition.org/miranda/9084

DOI: $10.4000 /$ miranda. 9084

ISSN: 2108-6559

\section{Publisher}

Université Toulouse - Jean Jaurès

Electronic reference

Myriam-Isabelle Ducrocq, "The Debate on Property during the First English Revolution 1647-1659 : A Historical Perspective", Miranda [Online], 13 | 2016, Online since 17 November 2016, connection on 16 February 2021. URL: http://journals.openedition.org/miranda/9084 ; DOI: https://doi.org/10.4000/ miranda.9084

This text was automatically generated on 16 February 2021.

\section{c) (i) $(9)$}

Miranda is licensed under a Creative Commons Attribution-NonCommercial-NoDerivatives 4.0 International License. 


\title{
The Debate on Property during the First English Revolution 1647-1659 : A Historical Perspective
}

\author{
Myriam-Isabelle Ducrocq
}

1 The aim of this paper is to provide a historical background to the radical proposals ${ }^{1}$ formulated by Thomas Spence concerning property, insofar as they are reminiscent of the debates that took place at the time of the First English Revolution. In Crusonia $(1782)^{2}$, the traveller and narrator describes life in the island where Robinson was once shipwrecked. The island is now populated by the offspring of European sailors and native women, who at first had retained the law of male primogeniture as applied in England, but soon discarded it and opted for new institutions. Having declared every man's right to "Liberty, Subsistence (and consequently to Land) and to be of the Legislature, and other Offices", the island's inhabitants called "the Malcontents" had proclaimed the abolition of landownership so that every parish become a corporation where everyone is allocated a tract of land and pays to the public treasury a rent apportioned to the land's value. The narrator confesses that where he expected to find "Anarchy, Idleness, Poverty, and Meanness" he sees "nothing but Order, Industry, Wealth, and the most pleasing Magnificence !" Such are the unexpected effects of what he "narrowly thought of a ridiculous Levelling Scheme". The opening of Crusonia contains many echoes of English seventeenth-century revolutionary period. The reproduction of a proto-English society in a faraway country is evocative of Henry Neville's Isle of Pines (1668), except that Crusonia's inhabitants are wiser in departing from what soon appears as a flawed social organisation ${ }^{3}$. The denomination of "Malcontents" evokes the way the General Council referred to "the Agitators" in the New Model Army, whereas the term "Levelling" alludes to the kind of projects born in the previous century, with a view to promoting a greater equality among the members of the Commonwealth trough the reform of property structures and political rights.

2 I will take the well-known Army debates of $1647-49$ as a starting point for this study not only because they are well documented ${ }^{4}$, but because beyond the pressing question of 
the king's fate they epitomize the conflicting views about property in revolutionary England and its relation to political rights. As Colonel Rich, one of the Putney protagonists, put it, the debates revealed two "extremes": on the one hand, the idea "[that] men that have no interest as to estate should have no interest as to election", on the other, the conviction "that they should have an equal interest" (63-64). However, as he pointed out, there may have been a middle way between on the one hand, connecting the voting rights to property rights, thus excluding the poor from civic representation, and on the other hand, disconnecting them altogether so as to allow manhood suffrage, which by the law of majority was bound to end in voting "equality of goods and estates" (63). This middle way consisted of a "distribution of election" so that "there may be a representative of the poor as well as the rich, and not to exclude all." (64) Here is an interpretative framework that helps us read various proposals for a better society that emerged in the wake of the civil wars. I will chronologically expose that of the Levellers, as expounded in the Agreements of the People and discussed at Putney, who stood for the extension of the franchise; that of the Diggers voiced by Gerrard Winstanley, who claimed collective property rights over the land; and that of James Harrington who derived political rights from economic power while proposing a more equalitarian distribution of property. It will be shown that all three positions engaged the understanding of such fundamental notions as liberty and equality.

\section{"Property... the most fundamental constitution" : the Putney Debates}

3 What took place at St Mary's Church in Putney (south London) in the Autumn of 1647 and again in the winter of 1648-49 was the debating of a declaration entitled An Agreement of the People, signed by sixteen regiments (nine of horsemen, seven of footmen) and presented to the General Council of Officers of the New Model Army. The authors vindicated what they called "the native rights" of "the freeborn people of England" which they hoped to see entrenched in law, at a time when they knew Cromwell and the Army grandees were negotiating the peace terms with King Charles I. They claimed a better representation in Parliament achieved though frequent elections every two years, a more equal distribution of seats throughout the country apportioned to the population and last but not least, popular sovereignty.

When A Case of the Army Stated claimed the payment of the arrears to the rank and file who had been fighting the royalist camp ${ }^{5}$, the Agreement called for a legal and political reward for the war effort. The demand for successive parliaments, which should meet regularly and be frequently renewed, as opposed to indefinite ones summoned at will by the sovereign, was of course not specific to the Levellers. It had been the battle cry of the Parliamentary camp and it had even been conceded by Charles I who had accepted to sign the Triennal Act in 1641, an act which required that Parliament should meet at least once in three years for a minimum period of fifty days. This was common ground throughout the Putney Debates. But there were other sources of disagreement.

5 After three days of intense debating (and praying) no consensus was reached. When an amended version of the Agreement was presented in the midst of the king's trial on January $20^{\text {th }} 1649$, "Ireton and Cromwell saw an opportunity to let the Agreement die a quiet death while the nation's attention was fixed upon the fate of their monarch" (Vallance 2009, 170). By March 1649, all the leaders of the Leveller movement were 
imprisoned ${ }^{6}$. What led the Army leaders to "let the Agreement die a quiet death" then ? Ireton may have sympathized with some of the Levellers' claims in principle, especially when it came to the extension of the franchise (Morton 215, Vallance 164), and may have buried it because political realism commanded it ; but the discussions reveal some insuperable divisions.

6 Colonel Thomas Rainborough and other Levellers ${ }^{7}$ advocated the extension of the franchise below the 40-shilling threshold and a better electoral distribution of seats throughout the country. This it should be noted did not amount to manhood suffrage but would have granted small proprietors and wage earners the right to vote, excluding servants, labourers and paupers to the extent that they were economically dependent on others. They grounded their claim in the existence of the native liberties Englishmen had been deprived of ever since the Norman invasion. They combined these liberties to natural liberties, so that "every Englishman that is an inhabitant of England should choose have a voice in the representatives" (Petty 61). In St Edward's Ghost : or, Anti-Normanisme (1646), Mark Overton had resorted to the topos of the Norman Yoke that has been well analysed by Christopher Hill and others ${ }^{8}$. As Joseph Franck noted :

A little more than a year later, during the debate at Putney, the myth of historical rights was more fully fused with the myth of inherent natural right, until, in combination, they became the most powerful weapon in the Leveller propaganda arsenal. (Franck 84)

7 Army Grandees, through the voice of Oliver Cromwell and Henry Ireton, stood firmly against such proposals. They perceived the far-reaching implications of positing equal rights for every man living in the community, every resident. First of all, it could mean granting a voice to strangers, a principle which ran contrary to the fundamental constitution of the realm "that no person that hath not a local and permanent interest in the kingdom should have an equal dependence in election [with those that have]" (Ireton 63). Secondly, and perhaps more importantly, they were keen to show that the notion of a Law of Nature on which the Levellers based their argument severely undermined the institution of property, one of the pillars of English society :

All the main thing that I speak for, is because I would have an eye to property. Let everyman consider with himself that he do not go that way to take away all property. For here is the case of the most fundamental part of the constitution of the Kingdom, which if you take away, you take all away, by that [...] if this be allowed, we are free, we are equal, one man must have as much voice as another [...] Upon these grounds, if you do, paramount [to] all constitutions, hold up this law of Nature, I would fain have any man show me their bounds, where you will end, and [why you should not] take away all property (Ireton 57).

While the more moderate Levellers like Maximilian Petty or Wildman proclaimed to be set against "Kings and Lords and property" - meaning the overwhelming power of the landed aristocracy - while denying to attack property per se, the more radical Rainborough or Sexby insistently questioned the connection between property and franchise : "I would desire to know how this comes to be a property in some men and not in others." (60-61)

Ireton's following declaration voices his ultimate trust in God's ways, however incomprehensible they may be, should He allow the Leveller principles to be adopted :

If God saw it good to destroy not only King and Lords, but all distinctions of degrees

- nay if it go further to destroy all property, that there's no such thing left, that

there be nothing at all of civil constitution left in the kingdom- if I see the hand of 
God in it I hope I shall with quietness acquiesce, and submit to it, and not resist it (Ireton 50).

10 He went on to express confidence that God will not let the Army "incur sin or bring scandal in the name of God and the name of the people of God" (Ireton 50). There is no doubt that with peace looming ahead, the Army victors and parliamentary Independents were returning to "the government policy as it affected the land, trading interests and foreign policy" (Morton 216) and that they became increasingly concerned with restoring public order. As Cromwell told them : "These things that you have now offered, they are new to us"; he recognized that the Agreement contained in it very great alterations of the fundamental laws of the realm that the people may not be ready to receive (7-8). A few days later, the Leveller leaders were examined before the Council of State set up to act as a temporary executive body before being sent to the Tower.

11 To Ireton who, though conceding that property was a human and not a divine institution, repeated he could not approve in his heart the destruction of property, a bitter Edward Sexby', replied :

I see that though liberty were our end, there is a degeneration from it [...] There are many thousands of us soldiers that have ventured our lives; we have had little propriety in the kingdom as to our estates, yet we have had a birthright. But it seems now, except a man hath a fixed estate in this kingdom, he hath no right in this kingdom. (69)

12 Cromwell and the Army Grandees proclaimed to be the defenders of liberty though. What they found much more difficult to accept, or found too dangerous to accept for the sake of the country's unity, was the "utter confusion" and "absolute desolation" which would result from implementing a greater equality in the system of representation (7) ${ }^{10}$. Not only would it "make England like the Switzerland country, one canton of the Swiss against another" (7), but it would put master and servant on an equal footing by making them "equal electors", so that "those that have no interest in the kingdom will make it their interest to choose those that have no interest. It may happen, that the majority may by law, not in confusion, destroy property" (63). The idea of democracy brought about a train of fears - confusion of rank, rivalry between the regions, both conducive to a state of anarchy. Equality, more than liberty, appears to have been the stumbling-block of the Putney Debates.

\section{"Once the earth becomes a common treasury again"11 : Winstanley and the Digger experiment}

13 In April 1649 a group of men set up a community on St George's Hill in the parish of Walton-on-Thames. Against the backdrop of severe poverty due to a series of bad harvests, they sought to put into practice the principles that Gerrard Winstanley had not ceased to defend in his writings, and started digging and planting the waste lands together. The land was conveniently located near the Windsor Great Forest, the resources of which the people could reclaim after the fall of the monarchy and the seizing of the Crown's lands. The group of Diggers amounted to twenty to thirty people who were offered meat, drink and clothes (Hill 1972, 110). The labourers were almost immediately rejected by locals, so in August Winstanley decided to move to the nearby community of Cobham where they were better accepted. For example, Gurney notes 
that John Coulton, "a yeoman farmer and a solid member of his local community" was one of those who joined Winstanley on St George's Hill and remained there until the end of their activity in April 1650 (Gurney 2007, 1-2). Overall the Digger experiment lasted one year ${ }^{12}$.

For Winstanley, tyrannical oppression by "kingly power" was irretrievably connected to the dispossession of the poor by the Crown and the landed gentry. This vision was anchored in a rational reading of the Bible :

And hereupon the earth, which was made to be a common treasury of relief for all, both beasts and men, was hedged into enclosures by the teachers and rulers, and the others were made servants and slaves. And the earth that is within this creation made a common storehouse for all, is bought and sold and kept in the hands of a few [...] (379).

He went on :

That we may work in righteousness, and lay the foundation for making the earth a common treasury for all, both rich and poor. That every one that is born in the land may be fed by the earth, his mother [...] not enclosing any part into any particular hand, but all as one man working together, and feeding together as sons of one father, members of one family; not one lording over another, but all looking upon each other as equals in the creation (380).

"Civil propriety is the curse", Winstanley declared. He saw a historical continuity between the Babylonian yoke over Israel and the Norman yoke over England, as in both cases "the freeholders or landlords must be the choosers." The "poor enslaved English Israelites" had been deprived of their means of subsistence by the conquest of the land and by the same token, had been deprived of their electoral voices. That is why Winstanley did not advocate any extension of the franchise, a system still based on private property. Tilling the common lands was the only means by which the people could retrieve and assert collective rights of property and be eventually freed from bondage (382-385).

17 As Christopher Hill described it, the Digger experiment "was a symbolic assumption of ownership of the common lands" (Hill 1972, 110). For local landowners and some observers, it amounted to illegal appropriation. Thus James Harrington famously referred to "robbers or levellers" (Pocock 1977, 292) ${ }^{13}$. But I would like to suggest that doing so, Harrington denounced the ill-consequences of Cromwell and the Army grandees' policy, and intervened in the ongoing debate about property in one of the directions pointed out by Colonel Rich at Putney.

\section{Harrington and the balance of property}

Rich had declared :

There may be a more equitable division and distribution than that he that hath nothing, should have an equal voice; and certainly there may be some other way thought of, that there may be a representative of the poor as well as the rich, and not to exclude all. (Woodhouse 63)

James Harrington certainly never went as far as to advocate some form of agrarian communism. The institution of private property remained one of the bases of his model republic depicted in The Commonwealth of Oceana (1656). However, what relates him to the Levellers and the Diggers is the way in which he linked economic inequalities to 
political exclusion and believed the reduction of such inequalities was at the core of a well-ordered commonwealth.

Harrington was not an actor of the Revolution; he was an eye witness to the fall of the monarchy as he had served as gentleman of the bedchamber to Charles I in captivity between 1647 and 1649 (Pocock 1-5). He was a theoretician who reflected on the historical mechanisms by which states maintained themselves or collapsed ${ }^{14}$. His conviction was that the ancient constitution had been overthrown because of imbalances in the distribution of property. To him, these imbalances could only be remedied by the entrenchment of an agrarian law inspired by the Roman Republic ${ }^{15}$.

Inequalities in the distribution of property primarily derived from the law of male primogeniture, which deprived the younger brothers in order to avoid the division of the estate. He humorously compared this process to the drowning of newborn puppies. A pillar of the monarchy and the aristocracy, where land and power rested within the hands of a few, such a law ran counter to the principles of a commonwealth : "If the monarchy could not bear such divisions [of property] because they tended to be a commonwealth, neither can a commonwealth connive at such accumulations, because they tend to a monarchy." (Pocock 237) ${ }^{16}$ Hence the need for a voluntary redistribution of property, not along levelling lines, but in way that :

every man who is at present possessed, or shall hereafter be possessed, of an estate in land exceeding the revenue of five thousand pounds a year, and having more than one son, shall leave his lands either equally divided among them, in case the lands amount unto above $2000 £$ a year unto each, or so near equally, in case they come under, that the greater part or portion of the same remaining unto the eldest exceed not the value of two thousand pounds revenue (Pocock 231).

Harrington was taking part in a long-standing debate as to whether the agrarian law had accelerated the fall of the Roman Republic which had adopted it. In this particular respect, he firmly opposed his master Machiavelli (Pocock 232-235). Conversely, he stood closer to the Leveller soldier Cowling who, during the Putney debates, had raised the following question: "whether the younger son have not as much right to the inheritance as the eldest" (64). In fact, several 1640s pamphlets had asked for a government intervention meant to restore a better distribution of land property. For instance, in August 1649, the Tyrannipocrit Discovered had attacked the new government of England for not establishing "an equality of goods and lands" (cited in Hill 1972, 116). Thus, it clearly appears that "The agrarian law was made famous by James Harrington's advocacy of it in Oceana (1656) from which many thinkers adapted the idea. But Harrington was only summing up a tradition." (Hill 1972, 115)

As seen above, Harrington's agrarian was not about achieving "an equality of goods and lands" but it was about preventing blatant discrepancies between the citizens of his ideal republic, inequalities which would inevitably result in civil strife : "Take the bread out of the people's mouths, as did the Roman patricians, and you are sure enough of a war, in which case they may be levellers; but our agrarian causeth their industry to flow with milk and honey." (Pocock 293) As the rest of the passage shows, this was a clear indictment of Cromwell's policy in the late 1640 s which had deprived the common soldiers of their pay and thus captured the public revenue. The term "leveller" remained a derogatory one, but Harrington attenuated it by asserting that social circumstances, not any ingrained wickedness, made people so. Similarly, the persistence of immovable castes who lived to receive the dividends of their property was a disgrace : 
The aristocracy is ravenous, and not the people. Your highwaymen are not such as have trades or have been brought up unto industry, but such whose education hath pretended unto that of gentlemen. (292)

bicameral Parliament, an institution he ceaselessly defended until the last hours of the Protectorate. It consisted of a senate elected among the richer proprietors replacing the hereditary House of Lords (three hundred); and a large popular assembly or prerogative tribe, composed of one thousand and fifty small proprietors (four-hundredand-fifty horsemen and six-hundred footmen) (Pocock 284). Contrary to the old system of government, each house would be ascribed a specific role, so that power would be equally distributed between the two: the Senate debating, the Prerogative tribe deciding. This, according to Harrington, would prevent a House from supporting a law that would supersede the other House's interest:

The over-balance in the suffrage remaining unto the foot by one hundred and fifty votes, you have, unto the support of a true and natural aristocracy, the deepest root of a democracy that hath been planted. (Pocock 284)

In addition, the members of the prerogative chamber and of the Senate would be elected and both houses would be renewed by third during annual elections, according to the principle of rotation so as to prevent the corruption of the people's representatives. 
ington staunchly believed in democracy as incarnated by a numerous popular assembly. On the eve of the Restoration, in The Art of Lawgiving (1659), he expressed impatience at the resistance he felt even among his fellow citizens, including those who had overthrown the monarchy ${ }^{17}$, against this notion of a popular assembly. Commenting on Thucydides (in Hobbes's translation) who recommended the combination of the few and the many to redress Athens:

But we in England are not apt to believe that to decree the sovereignty unto thousands were the way to make city or a nation recover of wounds or to raise her head. We have a loathing, we are sick of such thoughts. An assembly of the people sovereign! Nay, and an assembly of the people consisting in the major vote of the lower sort! (Pocock 676) discussions, vehiculed by seventeenth and eighteenth-century radicals and "commonwealthmen"18. Thomas Spence's proposal of a land plan was reminiscent of the agrarian law debated during the English Revolution. In some ways, it echoed Winstanley's views "in that it identified the private ownership of land as the source of inequality and evil in the country" (Vallance 231). On the other hand, Spence was highly defiant of "big government" and proposed that land should be owned by the parish and distributed among its inhabitants. This was quite different from the kind of centralizing system advocated by Winstanley or Harrington, for whom the agrarian was inscribed in the constitution of his ideal republic. However, the common thread between these thinkers was the way they connected the reform of society and the reform of property structures, a reform for which they deserve the name of "radicals".

Quite symptomatically, eighteenth-century designs involving a better distribution of property among men (and sometimes women) as the basis for a more equalitarian society, met with the same opposition as seventeenth-century ones. This is what one can read in this political tract circulated by the Association for preserving Liberty and Property against Republicans and Levellers in 1792 :

It appears to us, the tendency of these Opinions is, that we are voluntarily to surrender every thing we now possess; our Religion and our Laws; our civil Government and Civil Society; and that we are to trust to the formation of something New, upon the principles of Equality, and under the auspices of speculative men, who have conceived ideas of perfection that never yet were known in the World.

Thus, when in the midst of another revolutionary turmoil Edmund Burke denounced the destruction of property (Burke 141) and "the fabrication of a new government" 
(117) in France, the petitioners lamented the planned destruction of English institutions and their substitution by the dangerous brainchild of utopian thinkers.

\section{BIBLIOGRAPHY}

Printed or digitized primary sources

Burke, Edmund. Reflections on the Revolution in France (1790). London : Penguin Books, 1986.

Pocock, J.G.A. (ed.). Harrington, James. The Political Works of James Harrington. Cambridge :

Cambridge University Press, 1977.

Tract By the Association for preserving Liberty and Property against Republicans and Levellers at a meeting of Gentlemen at the Crown and Anchor Tavern, November 10, 1792, John Reeves, esq. in the Chair A, Signed by J. Moore, Secretary by order of the Society

(Bibliothèque Nationale de France )

Corns, Thomas N., Hughes, Ann, Loewenstein, David (eds.). The Complete Works of Gerrard Winstanley, Oxford : Oxford University Press, 2010.

Machiavelli, Niccolo. Discourses on the First Decade of Titus Livius, transl. N. Hill Thomson. London : Kegan Paul, Trench and Co., 2007 (1883).

Sharp, Andrew. The English Levellers. Cambridge : Cambridge University Press, 1998.

Spence, Thomas. A Supplement to the History of Robinson Crusoe being the History of Crusonia. Newcastle: printed and sold by T. Saint in 1782. http://thomas-spence-society.co.uk

--- The Constitution of Spensonia. 1803. http://thomas-spence-society.co.uk

Woodhouse, A.S.P. (ed.). Puritanism and Liberty. Being the Army Debates (1647-49) from the Clarke Manuscripts. London and Melbourne : Dent, Every Man's Library, 1986 (1938).

Secondary sources

Baker, Philip, Vernon, Elliott. Agreements of the People, the Levellers and the Constitutional Crisis of the English Revolution. London : Palgrave Macmillan, 2012.

Borot, Luc. "Richard Overton and Radicalism : the New Intertext of the Civic Ethos in Mid Seventeenth-Century England" in G. Burgess and M. Festenstein (eds.). English Radicalism 1550-1850. Cambridge : Cambridge University Press, 2007, pp. 37-61.

Burgess, Glenn. "Radicalism and the English Revolution" in G. Burgess and M. Festenstein (eds.). English Radicalism 1550-1850. Cambridge : Cambridge University Press, 2007, pp. 62-81.

--- The Politics of the Ancient Constitution : An Introduction to English Political Thought 1603-1642. Basingstoke : Macmillan, 1992.

Curelly, Laurent. " 'Our digging upon that Common is the talk of the whole land' : the story of the Surrey Diggers as told by contemporary newsbooks", in A. Bandry-Scubbi \& J.-J. Chardin (eds.), Spreading the Written Word in the English-Speaking World, Revue de la Société d'Études Anglaises et Américaines XVII-XVIIIe siècles, H.S. n² 2, 2010, 47-62. 
Cuttica, Cesare, Mahlberg, Gaby, eds. Patriarchal Moments: reading patriarchal texts. London: Bloomsbury, 2016.

Ducrocq, Myriam-Isabelle. « James Harrington, theoretician of an Equal Commonwealth : an eccentric figure in English political thought? » in S. Aymes-Stokes et L. Mellet (eds.). In and Out. Eccentricity in Britain. Cambridge : Cambridge Publishing Scholars, 2012, 105-121.

--- « The Commonwealth of Oceana (1656) : une brèche dans l'édifice patriarcal anglais à l'heure des Révolutions ?» in Inégalité(s) femmes-hommes et utopie(s) (Antiquité-XXI siècle), G. Leduc (ed.), Paris : L'Harmattan, 2017.

Foxley, Rachel. "Democracy in 1659 : Harrington and the Good Old Cause" in S. Taylor and G. Tapsell (eds.), The Nature of the English Revolution Revisited, 2013., pp. 175-196.

Franck, Joseph. The Levellers. Cambridge (Mass), Harvard UP, 1955.

Gurney, John. Brave Community. The Digger Movement in the English Revolution. New York and Manchester : Manchester University Press, 2007.

Hill, Christopher. The Intellectual Origins of the English Revolution. Oxford : Oxford University Press, 1965.

--- The World Turned Upside Down. London : Maurice Temple Smith, 1972.

Kishlansky, Mark. The Rise of the New Model Army. Cambridge : Cambridge University Press, 1979.

--- "Consensus Politics and the Structure of Debate at Putney", JBS (20), 1981.

Lurbe, Pierre. Le Joug normand. L'interprétation de la conquête normande dans la pensée politique anglaise (XVII-XVIIIe siècles). Caen : Presses Universitaires de Caen, 2004.

Lutaud, Olivier. Cromwell, Les Niveleurs, et la République. Paris : Aubier, 1967.

Macpherson, C. B. The Political Theory of Possessive Individualism. Oxford : Oxford University Press, 1962.

Mahlberg, Gaby. Henry Neville and English Republican Culture in the Seventeenth c. Dreaming of Another Game. Manchester: Manchester University Press, 2009.

Meiksins Wood, Ellen. Liberty and Property. A Social History of Western Political Thought from Renaissance to Enlightenment. London :Verso, 2012.

Mendle, Michael (ed.). The Putney Debates of 1647 : the Levellers and the English State. Cambridge :

Cambridge University Press, 2001.

Morrill, J.S. The Nature of the English Revolution. Essays by John Morrill. London : Longman, 1993.

Morton, A.L. A People's History of England. London : Lawrence and Wishart, 1994 (1938).

Pocock, J.G.A. The Ancient Constitution and the Feudal Law. Cambridge : Cambridge University Press, 1957 ( $\left.2^{\text {nd }} e d .1987\right)$.

--- The Machiavellian Moment. Florentine Political Thought and the Atlantic Tradition. Princeton and Oxford : Princeton University Press, 1975.

Robbins, Caroline. The Eighteenth-Century Commonwealthman : Studies in the Transmission, Development and Circumstances of English Liberal Thought from the Restoration of Charles II until the War with the Thirteen Colonies. Cambridge (Massachussets) : Harvard University Press, 1959.

Vallance, Edward. A Radical History of Britain. London : Little Brown, 2009.

Woolrych, Austin. Soldiers and Statesmen. Oxford : Oxford University Press, 1987. 
Wrightson, Keith. Earthly Necessities. Economic Lives in Early Modern Britain, 1470-1750. London : Penguin, 2000.

\section{NOTES}

1. Some authors have warned us against the indiscriminate use of the labels "radical" and "radicals" as that they tend to reify ideological divisions and run the risk of anachronism by overlooking the links between supposed radicals and tradition. Radicalism will be taken here as referring to "an attitude to the status quo" and "a demand for the structural transformation of an existing order". (Burgess 2007, 62-81)

2. Thomas Spence, A Supplement to the History of Robinson Crusoe being the History of Crusonia, Newcastle, printed and sold by T. Saint in 1782. In the following passage, I am referring to the text from the 1782 digitized by the Thomas Spence Society and available on their website: http:// thomas-spence-society.co.uk

3. For a recent analysis of Neville's Isle of Pines and republicanism, see Mahlberg 2009, 83-89.

4. The general secretary of the Army William Clarke took a verbatim record of them. For a discussion of the various editions of the Putney Debates, see Michael Mendle 2001, 1-18. Woodhouse based his edition on the Clarke Manuscript in Oxford (Clarke Ms 65, Worcester College). As the debates (and only the first three days) were taken in shorthand by Clarke, the editor took the liberty to reconstruct whole groups of words. These are the words between brackets. Whenever referring to the Debates I will refer to the Woodhouse edition.

5. For a treatment of the "bread-and-butter grievances" at stake, see Morrill's "The Army Revolt" (1977) in Morrill 1993, 307-331.

6. These were John Lilburne, Richard Overton, William Walwyn and Thomas Prince.

7. A political actor remarked in 1651 "The word Leveller is a term of abuse cast upon many a person for holding forth of righteous principles" (William Hartley. The Prerogative Passing Bell, 9-10 quoted in Hill 1972, 122. The authors of the Agreements of the People declared they stood in defence of "legal fundamental liberties" or native liberties; only the Diggers claimed to be the "true Levellers" Cf. The True Levellers' Standard Advanced (1649) by William Everard, Gerrard Winstanley, John Taylor and others (Woodhouse 379-386)

8. Hill 1997 (1965), Pocock 1957, 1987, Burgess 1992, Lurbe 2004.

9. Edward Sexby is the author of the famous pamphlet in favour of tyrannicide Killing No Murder (1657) advocating Cromwell's assassination.

10. There seems to be a degree of nuance between Cromwell and Ireton on that point as Ireton proclaimed "I am agreed with you if you insist upon a more equal distribution of elections, I will agree with you, not only to dispute for it, but to fight for it and contend for it." (77)

11. The True Levellers' Standard Advanced (Woodhouse 380). Whenever quoting from this text, I will refer to the Woodhouse edition.

12. There seems to have been other Digger communities, or at least sympathisers, in the southern part and central part of the country. Cf. Hill 1972, 124-128.

13. In the next passage, I will refer to the Pocock edition of Harrington's Political Works.

14. He described himself as a "political anatomist" whose complex description of the body politic was "understood by so few" (656).

15. He became more politically active in the later years of the Protectorate when he and others ran constitutional debates within the Rota Club, which came up with a draft constitution presented to the Rump Parliament in 1659. Cf. Foxley 2013; Ducrocq 2014.

16. Insofar as the law of male primogeniture was the main foundation of hereditary monarchy and aristocracy, notably expounded by Sir Robert Filmer in Patriarcha or the Natural Power of Kings (posth.1679), most of radical and republican thinkers proceeded to a scathing critique of it, to the 
point that seventeenth-century republicanism can be seen as "anti-patriarchalism". This does not mean to say that all radicals or republicans asserted gender equality, quite the contrary. $\mathrm{Cf}$. Mahlberg 2009; Cuttica and Mahlberg 2016; Ducrocq 2017.

17. We may quote Presbyterians like Prynne, Independents like Ireton, or other supporters of the Protectorate like Milton or Stubbe. Cf. Ducrocq 2014.

18. This umbrella term came to designate a group of political thinkers and activists who from the First English Revolution onward defended such principles as limited government, republicanism, parliamentary reform, the rule of law, religious toleration in the name of natural rights and individual liberty. Cf. Robbins 1959; Pocock 1975.

\section{ABSTRACTS}

The aim of this paper is to provide a historical background to the radical proposals formulated by Thomas Spence concerning property, to the extent that they are reminiscent of the debates that took place at the time of the First English Revolution. I will start with the well-known Army debates of 1647-49 not only because they are well documented, but because, beyond the pressing question of the king's fate, they epitomize the conflicting views about property in revolutionary England and its relation to political rights. I will then briefly examine Gerrard Winstanley's views on property which underlay the communist experiment on St George's Hill of 1649. I will then turn to the republican thinker James Harrington insofar as he shared with the Levellers and the Diggers the belief that imbalances in the distribution of property was key to understand the political transformations that the country experienced in the 1640s. His agrarian law was one the pillars of his ideal republic.

Cet article se propose de fournir un arrière-plan historique aux propositions radicales formulées par Thomas Spence sur la question de la propriété, car elles portent la marque des débats qui eurent lieu au moment de la Première Révolution anglaise. Je prendrai pour point de départ les célèbres débats de l'Armée de 1647-49, non seulement parce que ceux-ci nous sont connus grâce à un fonds d'archives important, mais aussi parce qu'au-delà de la question brûlante du sort du roi, ils offrent un résumé des points de vue parfois antagonistes qui s'exprimaient dans l'Angleterre révolutionnaire sur la propriété, dans sa relation avec les droits politiques. J'examinerai ensuite brièvement les conceptions de Gerrard Winstanley qui sous-tendent l'expérimentation communiste de St George's Hill de 1649. Je me tournerai enfin vers le penseur républicain James Harrington car il partageait avec les Levellers et les Diggers la conviction que les inégalités dans la répartition de la propriété étaient la clé pour comprendre les bouleversements politiques que le pays avait connus dans les années 1640 . Sa loi agraire constituait l'un des piliers de sa république idéale. 
INDEX

Keywords: Radicalism, English Revolution, primogeniture, liberty, voting rights, Levellers, Norman yoke, Civil War, law of nature, Diggers, tyranny, common lands, agrarian law, utopia, social mobility, parliamentary reform

Mots-clés: radicalisme, propriété, Révolution anglaise, primogéniture, liberté, égalité, droits civils, Niveleurs, joug normand, guerre civile, droit naturel, loi naturelle, ordre public, Diggers, tyrannie, communs, loi agraire, utopie, mobilité sociale, réforme parlementaire.

\section{AUTHORS}

\section{MYRIAM-ISABELLE DUCROCQ}

Maître de conférences

Université Paris Ouest-Nanterre-La Défense

mducrocq@u-paris10.fr 